***Reprinted with permission. No further reproduction is authorized without written permission from the American Meteorological Society. This version of the document is not the version of record. Figures and/or pictures may be missing from this format of the document. ${ }^{* * *}$

\title{
Impacts of an Extreme Early-Season Freeze Event in the Interior Pacific Northwest (30 October-3 November 2002) on Western Juniper Woodlands
}

\author{
PAUL A. KNAPP* \\ Department of Anthropology and Geography, Georgia State University, Atlanta, Georgia \\ PETER T. SoulÉ \\ Department of Geography and Planning, Appalachian State University, Boone, North Carolina
}

(Manuscript received 6 October 2004, in final form 4 February 2005)

\begin{abstract}
In mid-autumn 2002, an exceptional 5-day cold spell affected much of the interior Pacific Northwest, with minimum temperatures averaging $13^{\circ} \mathrm{C}$ below long-term means (1953-2002). On 31 October, minimum temperature records occurred at 98 of the 106 recording stations, with records lowered in some locations by $9^{\circ} \mathrm{C}$. Calculation of recurrence intervals of minimum temperatures shows that $50 \%$ of the stations experienced a $>500$-yr event. The synoptic conditions responsible were the development of a pronounced high pressure ridge over western Canada and an intense low pressure area centered in the Intermountain West that promoted strong northeasterly winds. The cold spell occurred near the end of the growing season for an ecologically critical and dominant tree species of the interior Pacific Northwest-western juniper-and followed an extended period of severe drought. In spring 2003, it became apparent that the cold had caused high rates of tree mortality and canopy dieback in a species that is remarkable for its longevity and resistance to climatic stress. The cold event altered western juniper dominance in some areas, and this alteration may have long-term impacts on water budgets, fire intensities and frequencies, animal species interrelationships, and interspecific competition among plant species.
\end{abstract}

\section{Introduction}

An exceptional early season cold spell affected much of the Pacific Northwest (PNW) from 30 October through 3 November 2002. On 31 October, 20 weather stations in Oregon recorded all-time record lows for October (Taylor 2003). Preexisting records for low temperatures, often based on approximately a century of data collection, were lowered by $5.5^{\circ}-9^{\circ} \mathrm{C}$ at many stations. The Arctic outbreak occurred after three consecutive years of drought in the interior PNW (i.e., east of the Cascade Range) and was immediately preceded by five consecutive months of extreme drought condi-

* Current affiliation: Department of Geography, The University of North Carolina at Greensboro, Greensboro, North Carolina.

Corresponding author address: Paul A. Knapp, Department of Geography, The University of North Carolina at Greensboro, Greensboro, NC 27402-6170.

E-mail: paknapp@uncg.edu tions (NCDC 2004a). This unusual combination of record cold and drought affected the western juniper ( $J u$ niperus occidentalis var. occidentalis) woodlands of the arid and semiarid interior Pacific Northwest (T. Deboodt, Oregon State University Extension Agent, 2004, personal communication; Savonen 2003).

Western juniper is the most common tree species in the interior PNW. It is most dominant in central and eastern Oregon, where it occupies approximately two million hectares (Gedney et al. 1999), but the species extends into portions of Washington, southeast Idaho, northeast California, and Nevada (Soulé et al. 2004). It is long-lived (>1600 yr) and exhibits high resilience to environmental perturbations, because it has high drought tolerance (Knapp et al. 2004) and disease resistance (Knapp and Soulé 1999). Western juniper mortality is typically associated with senescence; and, in the absence of major fires, it is uncommon to observe trees either dead or with severe limb dieback. Western juniper is an ecologically significant species because it provides a critical wildlife habitat for herbivores and avian 
species, but the habitat value of these woodlands may decline as increasing density and cover reduce plant diversity (Miller et al. 2004). Further, juniper afforestation that has occurred during the past $130 \mathrm{yr}$ (Soulé et al. 2003) has created several land management issues (Miller et al. 2004), including changes in forage production, soil erosion, possible declines in subsurface flow, and declines in biological diversity. Thus, the ecological significance of this rare severe freeze event may be large.

Given the life-history characteristics of western juniper, range managers in central Oregon were intrigued that so many juniper trees were showing visual signs of stress (needles turning orange) in the early spring of 2003. By May of 2003, many of these trees had died; others had only significant branch dieback. Investigations into the spatial extent of recent juniper mortality show that the impacted areas range from $41^{\circ}$ to $45^{\circ} \mathrm{N}$ and from $119^{\circ}$ to $121.5^{\circ} \mathrm{W}$ (T. Deboodt 2004, personal communication). The area of affected western juniper was initially (i.e., summer 2003) estimated to be $3 \%$ of the total range, but the area continues to increase through time (T. Deboodt 2004, personal communication; R. Halvorson, Prineville, OR, Bureau of Land Management District Botanist, 2004, personal communication).

In this paper, we examine the spatial patterns of the unseasonable cold spell throughout the interior PNW and place the freeze event in a historical context. We identify the synoptic conditions that were associated with the record cold and describe the drought conditions that preceded the event. We then discuss some of the ecological consequences of the freeze, including the possibility that extreme unseasonable cold events may factor into ecotonal shifts within the range of western juniper.

\section{Methods}

We used daily minimum temperature data extracted from National Climatic Data Center (NCDC) Summary of the Day (1867-2002) files (NCDC 2004b). We selected all sites located within $40^{\circ}-49^{\circ} \mathrm{N}$ and $116^{\circ}-$ $122^{\circ} \mathrm{W}$, because this region both approximates the geographic range of western juniper and represents the core area that experienced record cold. Each selected station had records 1) beginning in 1953 or earlier and continuing through 2002,2) with data coverage of $90 \%$ or greater (average $=96.5 \%$ ), and 3 ) with minimum temperature data available for 30 October -3 November 2002. The final data file consisted of 106 stations in five states (Washington, Oregon, California, Idaho, and Nevada) for the period from October 1953 through November 2002.
Although the Arctic outbreak occurred from 30 October through 3 November, we focused our analysis on 31 October, which was the coldest day of the event for much of the interior PNW. Thus, for 31 October for each of the 106 stations, we determined the following: 1) minimum temperature, 2) departure from the 50-yr mean minimum, 3) whether a record minimum was set, 4) the departure from the next coldest 31 October, and 5) recurrence intervals associated with the minimum temperature. All of these data were mapped over a physiographic base map with the geographic range of western juniper identified (USGS 1999). Isotherms were layered over the base map using the ordinary kriging interpolation application in the proprietary ArcMap software's Spatial Analyst component (Childs 2004). Graduated-cylinder maps were created using a rangegrading technique in which data were separated into classes and assigned a proportional symbol of designated size. The Jenks optimal data classification method (Jenks 1977), which quantitatively identifies classes based on natural breaks, was used for Fig. 3, described in section $3 a$.

We calculated the statistical recurrence interval (RI) for the 31 October event following a method outlined by Kite (1988). This method uses standardized $Z$ scores from the normal probability distribution to examine beyond the period of record in determining the rarity of an event. Because the probability distribution at the majority of stations $(87 \%)$ was not statistically different from the normal distribution (significance level $\alpha=$ 0.05 ), we opted not to transform the data (e.g., through logarithmic transformation) to force normality. Although RIs are an effective means to place the climatic event in a broader historic context, a strict physical interpretation of the results (e.g., the 1-in-1000-yr event) is not applicable because the rarity of extreme events may be magnified.

To help to place the drought conditions preceding the freeze event into historical perspective, we examined Palmer drought severity index (PDSI; Palmer 1965) values from Oregon's Climatic Division 7, which covers the majority of the western juniper range (NCDC 2004a). Daily weather maps and 500-hPa charts were electronically accessed from the National Oceanic and Atmospheric Administration (NOAA) Daily Weather Map Web site (NOAA 2004) for 30 October-3 November.

\section{Results \\ a. Temperatures}

For 31 October, minimum temperatures ranged from $-3^{\circ}$ to $-24^{\circ} \mathrm{C}$, with the coldest temperatures recorded 


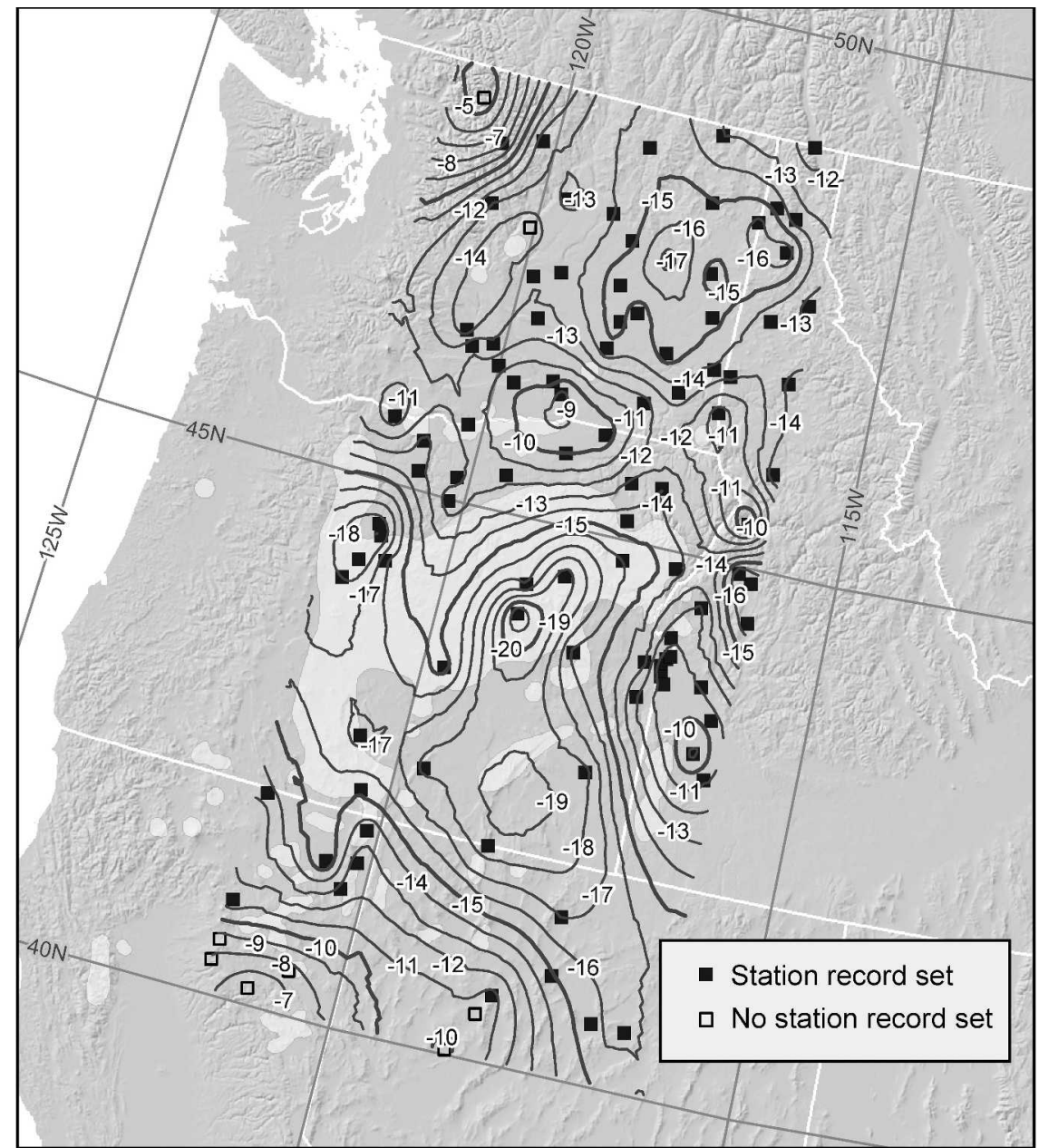

FIG. 1. Minimum temperatures for 31 Oct $2002\left({ }^{\circ} \mathrm{C}\right)$, shown by isotherms. Station location is marked by solid squares if a record was set and by open squares in the absence of a record. The lighter shading shows the natural range of western juniper (NCDC 2004a).

in central Oregon in the geographical center of the western juniper range (Fig. 1). Minimums exhibited geographical variability, with less extreme cold conditions occurring in north-central Washington, the Columbia River gorge, and northern California, and were correlated with elevation (correlation coefficient $r=$ $-0.33 ; p<0.001$ ). Record lows were observed for 98 of the 106 stations. Thirteen stations recorded minimums at or below $-17.8^{\circ} \mathrm{C}\left(0^{\circ} \mathrm{F}\right)$. Departures from the 1953-2002 average ranged from $4.5^{\circ}$ to $18^{\circ} \mathrm{C}$, with the greatest departures occurring in central Oregon and central Washington (Fig. 2). A similar pattern exists for how much colder this event was when compared with all other records since 1953 (Fig. 2). The recurrence intervals, ranging from 9 to $>500 \mathrm{yr}$, reveal the exceptional nature of this cold event. Fifty percent of all stations experienced an RI of $\geq 500 \mathrm{yr}$ (Fig. 3).

\section{b. Drought severity}

Beginning in October of 1999, 37 consecutive months with negative PDSI values (i.e., drought conditions) were recorded in Oregon's Climatic Division 7 prior to the autumn 2002 freeze. The mean PDSI during this period was -3.2 , indicating severe drought conditions. More impressive was that the mean PDSI for the 2002 hydrologic year (October 2001-September 2002) approached -4.2 , which ranks 5 th in the list of most severe drought years between 1895 and 2003.

\section{c. Synoptic conditions}

The 500-hPa charts for 30 October 2002 show the presence of a well-defined (Pacific) low pressure area centered at approximately $50^{\circ} \mathrm{N}, 150^{\circ} \mathrm{W}$; a high pressure area centered at $60^{\circ} \mathrm{N}, 130^{\circ} \mathrm{W}$; and another (interior West) low centered at $50^{\circ} \mathrm{N}, 110^{\circ} \mathrm{W}$ (Fig. 4). A 


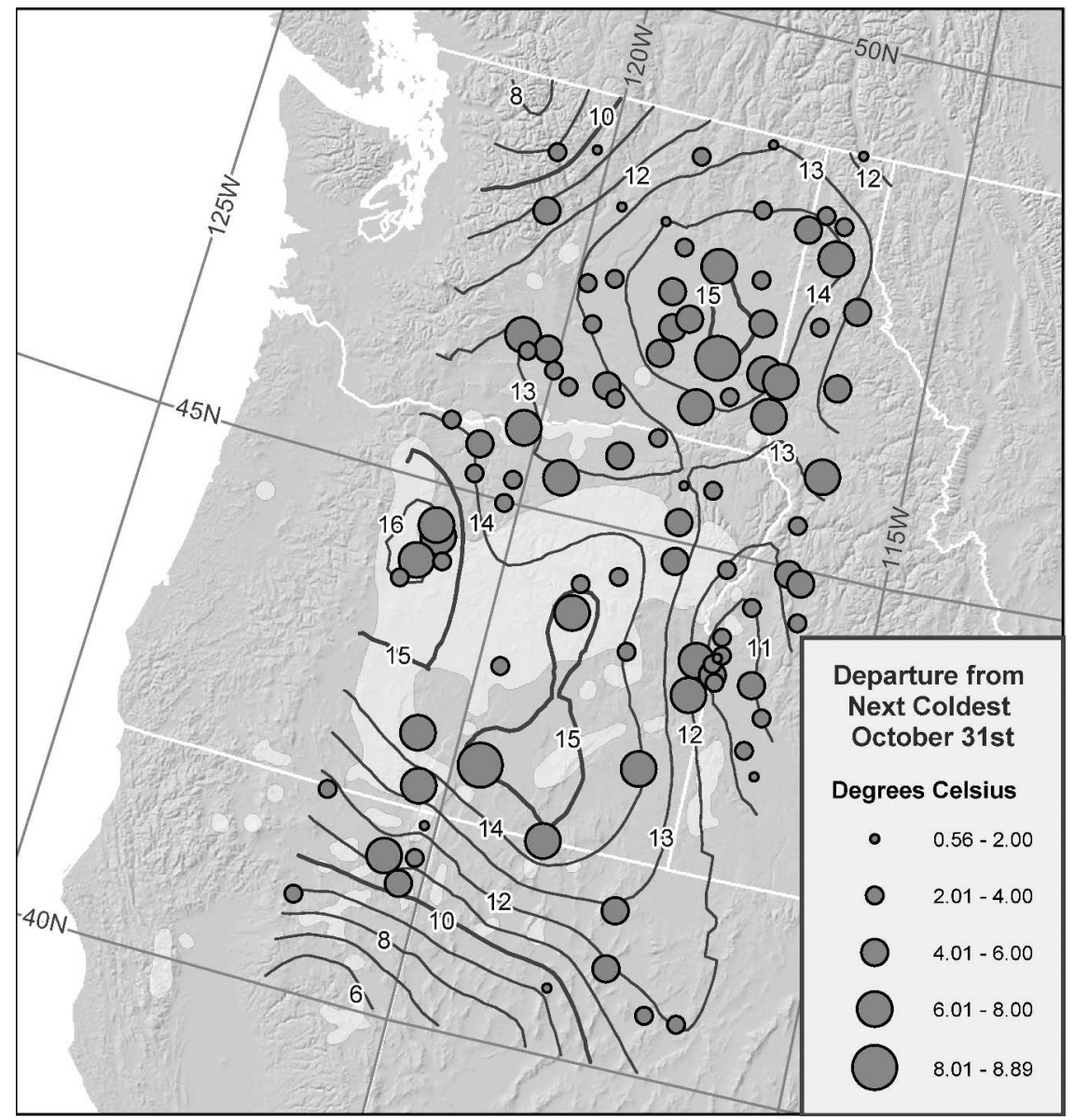

FIG. 2. Isotherms $\left({ }^{\circ} \mathrm{C}\right)$ represent departures for 31 Oct 2002 from the 1953-2002 mean daily temperature, with circle size indicating departure from the previous record minimum temperatures at weather stations $(n=98)$. Stations that did not experience record lows $(n=8)$ are not shown. The lighter shading shows the natural range of western juniper (NCDC 2004a).

similar pattern is seen on 31 October, but with increased amplitude and a tightening of the interior West low. The pattern remains intact through 2 November, but with a progressive decrease in amplitude. In association with this pattern and tight pressure gradient, a strong northeasterly flow occurred across the affected region, bringing with it an Arctic air mass.

\section{Discussion}

By all measures, the late October-early November cold spell was a rare meteorological event. Record minimums based on 50 -yr averages occurred at $94 \%$ of all stations, often by $5^{\circ} \mathrm{C}$ or greater, and the associated RIs were extreme. The significance of this event extends beyond its meteorological/climatological rarity because of the ecological consequences. Trees that were killed or are experiencing dieback likely re- sponded to exposure to the exceptionally cold temperatures before the individuals had fully undergone the physiological process of cold hardening. If so, the sudden onset of cold likely caused freezing that led to structural damage of xylem cell membranes (Sharrow 2004). In turn, dissolved air within the xylem cells was forced out by the expanding ice crystals, creating "seed bubbles" that interrupted the flow of the xylem water column and led to the drying (i.e., dying) of the tissues above the interrupted flow (Sharrow 2004, p. 6). Further, the ability to repair or replace damaged xylem cells in the following spring (Sharrow 2004) may have been compromised because the trees were experiencing the physiological stress of an extended drought.

At least two potentially climatically related stresses occurred to western juniper in the 24-month period from November of 2002 through October of 2004. First, PDSI values in Oregon's Climatic Division 7 remained 


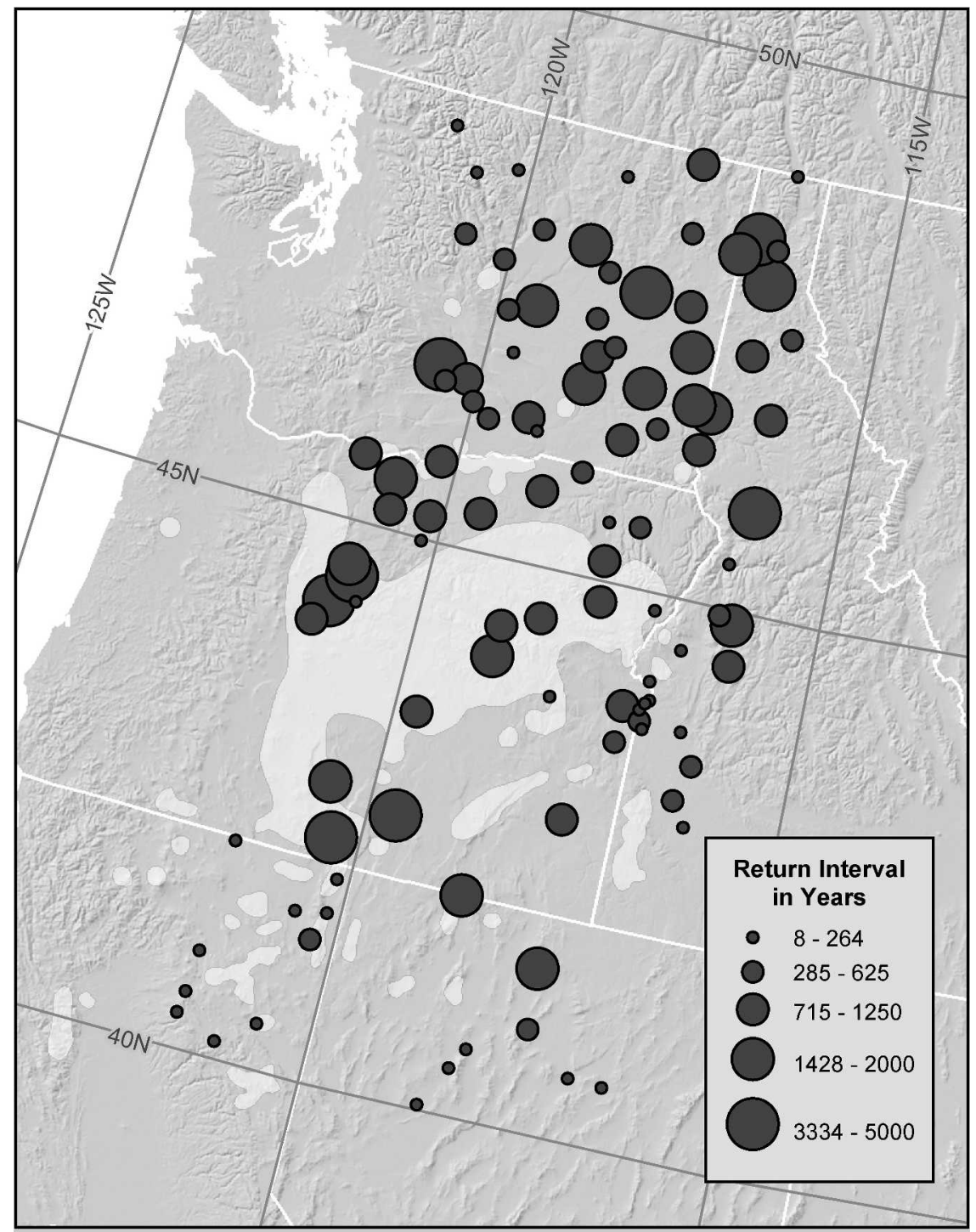

FIG. 3. Recurrence interval (years) for 31 Oct 2002 minimum temperatures at each of the 106 weather stations based on the 1953-2002 record. Circle size at each station is proportional with groupings based on natural breaks in the data. The lighter shading shows the natural range of western juniper (NCDC 2004a).

consistently below normal, with mean values of -3.6 [severe drought as defined by Palmer (1965)]. Second, a subsequent out-of-season cold event occurred a year after the 2002 event. This event was less severe and of much shorter duration than the 2002 freeze, with large departures from normal minimum temperatures largely occurring only on 1 November 2003 . For example, temperatures at the 10 Oregon sites with the greatest departure from the normal low temperature for 31 October 2002 (the coldest day of the event) were $-18.4^{\circ} \mathrm{C}$, and for 1 November 2003 they were $-13.7^{\circ} \mathrm{C}$. Although the possibility of additional foliar damages to western juniper from the 2003 freeze event exists, they are most likely related to the 2002 event coupled with continuing stresses from the extended period of drought conditions.

Exceptional minimum temperatures that cause canopy dieback may provide an entry point for fungal pathogens that cause heart rot. Knapp and Soulé (1999) examined 12 tree-ring chronologies of western juniper in the interior PNW and suggested that the fungal pathogen Antrodia juniperina was the probable cause of a widespread heart rot occurrence between 1730 and 1749. They found significant correlations between lower elevation and infection prevalence, suggesting a meteorological connection (i.e., cold-air drainage) that 


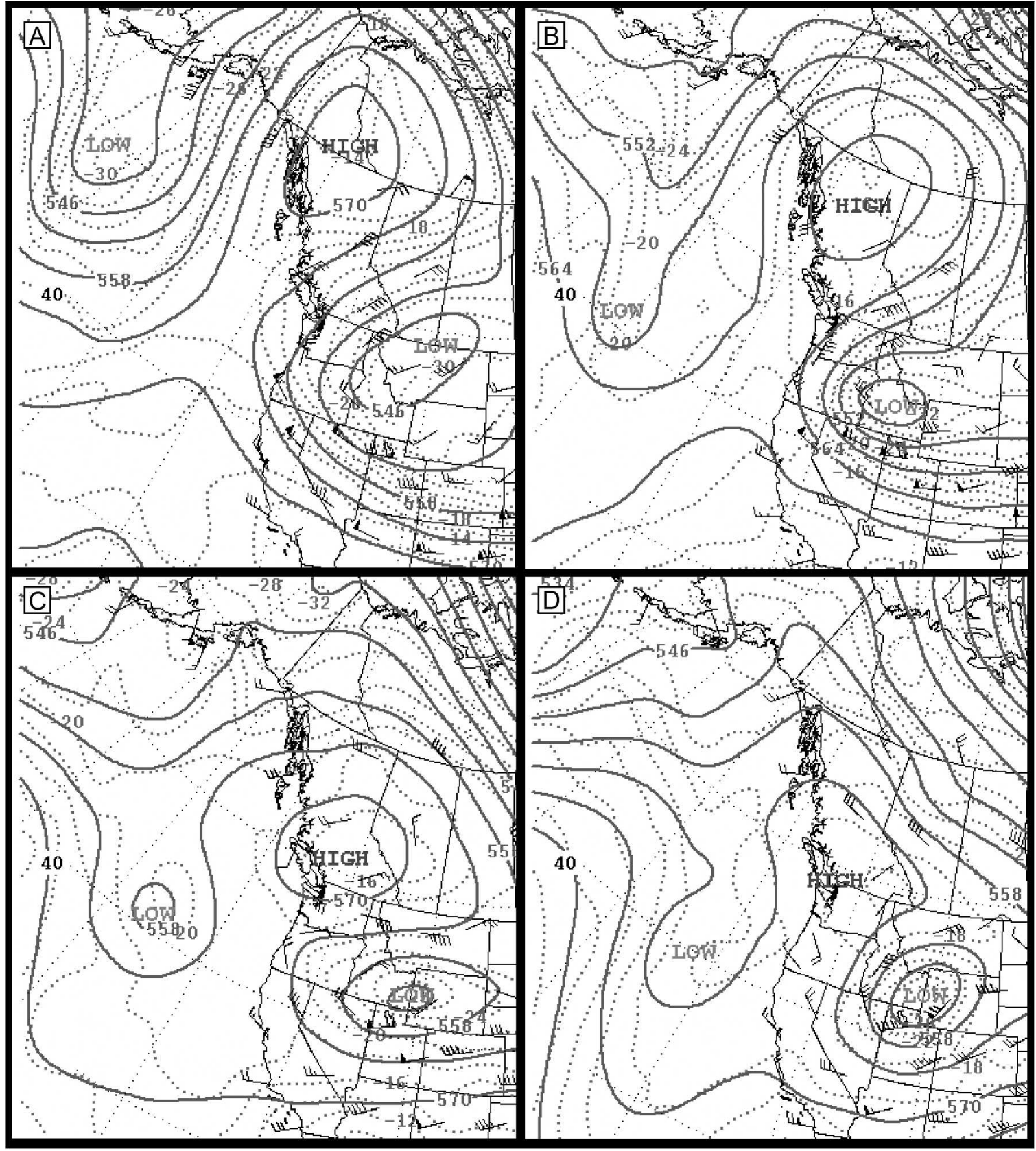

FIG. 4. The 500-hPa charts for (a) 30 Oct, (b) 31 Oct, (c) 1 Nov, and (d) 2 Nov 2002 (reproduced from NOAA 2004).

appears to be supported by our results [i.e., Fig. 1 in Knapp and Soulé (1999) shows a pattern of infection intensity associated with the lowest temperatures shown in Fig. 1 of our paper]. Conversely, extreme cold may potentially benefit western juniper growth. In northern California, for example, a period of record unseasonable cold in 1932 led to heavy mortality of the parasitic mistletoe species Phoradendron densum, hosted by western juniper. Thus, unseasonable cold may act as a temperature control of parasitic pathogens (Wagener 1957).

The possibility of shifting ecotones of western juniper range is an intriguing ecological consequence of the record cold event. Within the last century there has been a dramatic expansion of western juniper (Gedney et al. 1999), with concurrent increases in cover (Knapp and Soulé 1998), density (Soulé et al. 2003), and rates of establishment (Soulé et al. 2004). This recent period of 
afforestation is attributed to the synergistic influences of climate, biological inertia, and anthropogenic disturbance (domestic livestock grazing and fire exclusion) (Soulé et al. 2003, 2004). The extreme, out-of-season temperature event of 2002 may provide an alternative explanation for the waxing and waning of western juniper cover, density, and establishment. Whereas expanding ecotonal boundaries of western juniper range are often linked to favorable climatic conditions and land use activities (e.g., Miller and Wigand 1994; Soulé et al. 2004), unfavorable climatic events such as extreme freezes prior to cold hardening could serve as a regulating factor by causing ecotonal boundary contraction.

This event has altered the density and cover of western juniper, with possible influences on water budgets (e.g., Eddleman et al. 1994), fire intensities and frequencies (e.g., Burkhardt and Tisdale 1976; Miller and Rose 1999; Miller et al. 2001), and wildlife (e.g., Miller et al. 2001). The event serves as an example that occasionally a rare combination of climatological and meteorological events can occur that may impart a longlasting legacy to ecosystem dynamics.

Acknowledgments. This study was funded by grants from Georgia State University (RIG FY05-44) and the Appalachian State University Research Council. We thank Ron Halvorson for providing information on affected western juniper sites in central Oregon and Jeffrey Johnson and James Greg Dobson for their fieldwork assistance. We also thank Elaine Hallisey for the production of Figs. 1-3. The constructive comments of three anonymous reviewers significantly strengthened this paper, and we are grateful for their insights.

\section{REFERENCES}

Burkhardt, J. W., and E. W. Tisdale, 1976: The causes of juniper invasion in southwestern Idaho. Ecology, 57, 472-484.

Childs, C., 2004: Interpolating surfaces in ArcGIS Spatial Analyst. ArcUser Newsletter, July-September 2004. [Available online at http://www.esri.com/news/arcuser/0704/files/ interpolating.pdf.]

Eddleman, L. E., R. F. Miller, P. M. Miller, and P. L. Dysart, 1994: Western juniper woodlands of the Pacific Northwest: Science assessment. Department of Rangeland Resources, Oregon State University, Special Report, 132 pp.

Gedney, D. R., D. L. Azuma, C. L. Bolsinger, and N. McKay, 1999: Western juniper in eastern Oregon. USDA Forest Service General Tech. Rep. PNW-GTR-464, 53 pp.

Jenks, G. F., 1977: Optimal data classification for choropleth maps. Department of Geography, University of Kansas, Occasional Paper No. 2, 25 pp.
Kite, G. W., 1988: Frequency and Risk Analysis in Hydrology. Water Resources Publications, 257 pp.

Knapp, P. A., and P. T. Soulé, 1998: Recent western juniper ( $J u-$ niperus occidentalis) expansion on a protected site in central Oregon. Global Change Biol., 4, 357-367.

_ , and _ 1999: Geographical distribution of an 18th century heart rot outbreak in western juniper (Juniperus occidentalis ssp. occidentalis Hook). J. Arid Environ., 41, 247-256.

— - — , and H. D. Grissino-Mayer, 2004: Occurrence of sustained droughts in the interior Pacific Northwest (A.D. 17331980) inferred from tree-ring data. J. Climate, 17, 140-150.

Miller, R. F., and P. E. Wigand, 1994: Holocene changes in semiarid pinyon-juniper woodlands. Bioscience, 44, 465-474.

_ croachment in sagebrush steppe. J. Range Manage., 52, 550559.

— C. Baisan, J. Rose, and D. Pacioretty, 2001: Pre- and postsettlement fire regimes in mountain big sagebrush steppe and aspen: The northwestern Great Basin. Final Report to the National Interagency Fire Center, Eastern Oregon Agricultural Research Center, Oregon State University, 28 pp.

— J. D. Bates, T. J. Svejcar, F. B. Pierson, and L. E. Eddleman, 2004: Biology, ecology, and management of western juniper (Juniperus occidentalis). Oregon State University Agricultural Experiment Station Tech. Bull. 152.

NCDC, cited 2004a: Palmer drought severity indices, 1895-2003, Oregon Climate Division 7. [Available online at http:// climvis.ncdc.noaa.gov/cgi-bin/ginterface.]

— , 2004b: Summary of the Day (1867-2002). Earth Info, Inc., CD-ROM.

NOAA, cited 2004: Daily weather maps. [Available online at http://www.hpc.ncep.noaa.gov/dailywxmap.]

Palmer, W. C., 1965: Meteorological drought. U.S. Weather Bureau Research Paper No. 45, 58 pp.

Savonen, C., 2003: Fall freeze cause of spring's w. juniper damage and dieback. OSU News and Communication Services News Release, 12 May, 1 pp.

Sharrow, S. H., 2004: Cativation may explain winter damage to rangeland vegetation. The Grazier, No. 321, 5-7.

Soulé, P. T., P. A. Knapp, and H. D. Grissino-Mayer, 2003: Comparative rates of western juniper afforestation in southcentral Oregon and the role of anthropogenic disturbance. Prof. Geogr., 55, 44-56.

,-- , and — 2004: Human agency, environmental drivers, and western juniper establishment history during the late Holocene. Ecol. Appl., 14, 96-112.

Taylor, G. H., cited 2003: Early season Arctic outbreak, OctoberNovember 2002. College of Oceanic and Atmospheric Sciences, Oregon State University. [Available online at http:// www.ocs.orst.edu/arctic1002.html.]

U.S. Geological Survey, cited 1999: Digital representation of "Atlas of United States Trees" by Elbert L. Little, Jr. (and other publications). [Available online at http://climchange.cr.usgs. gov/data/atlas/little/.]

Wagener, W. W., 1957: The limitation of two leafy mistletoes of the genus Phoradendron by low temperatures. Ecology, 38, 142-145. 